This is the author-accepted version, after reviewer comments but before copyediting. The authoritative version is available at

http://www.tandfonline.com/doi/full/10.1080/14650045.2014.994609.

\title{
'We are Sitting on a Time Bomb': A Multiperspectival Approach to Inter-National Development at an East African Border
}

\author{
William L Allen, University of Oxford
}

\begin{abstract}
Recent discussion in critical border studies has reaffirmed the validity and necessity of multiperspectival approaches which move beyond state-centric outlooks to include diverse viewpoints of people at or on borders. One understudied aspect of everyday border life involves how international development organisations fit within wider dynamics of crossborder activities. Drawing upon experiences of development projects at a key border crossing between Kenya and Uganda, I explore (1) how perceptions of risk and danger contribute to constructions of the border towns as places in need of development interventions, and (2) how this border also adds to practical and logistical concerns already held by development organisations as they deliver these interventions. I argue that the place-based mix of location, material forms, and perceptions or practices impacts how 'inter-national development' is rationalised in border regions.
\end{abstract}

\section{INTRODUCTION}

The border is not something that straightforwardly presents itself in an unmediated way. It is never simply 'present', nor fully established, nor obviously accessible. Rather, it is manifold and in a constant state of becoming. ${ }^{1}$

In 2005, the United States Agency for International Development (USAID) launched a major project called 'Regional Outreach for Addressing AIDS through Development Strategies' (ROADS) across eleven countries in East, Southern, and Central Africa. This was later extended under the acronym of ROADS II in 2009. Implemented by USAID East Africa, and led by the development organisation Family Health International (FHI), ROADS II aims to "leave communities stronger by linking underserved, remote and vulnerable mobile populations and communities to HIV/AIDS and other critical health services". ${ }^{2}$ It does this by delivering new, as well as supporting existing medical, educational, and economic development interventions to towns and cities located along highway transport corridors, especially those at international borders.

As FHI's own literature explains, transport corridors present particular challenges and opportunities for delivering these objectives: 
The transport corridors of east, central, and southern Africa are economic lifelines that link countries with their neighbours, serving as pathways for trade and engines to expand local economies. They are also major transmission routes for HIV. People working and living along these corridors - truck drivers, traders, business people, employees of bars and lodgings, border and customs officers, and others - are at elevated risk of HIV infection. ${ }^{3}$

Initial conversations with ROADS II partners in the border towns revealed that movement along these corridors was strongly perceived to be the main source of problems for public health. One representative characterised the local situation in serious terms:

We have truckers moving from Mombasa along the Great North Road. They are to us a concern because wherever they rest, they have sexual encounters with different people, unprotected sex.... Truckers don't only have live sex with sex workers; they have live [unprotected] sex with school children because there are so many schools around. We see it is a very big problem; we are sitting on a time bomb. ${ }^{4}$

Perceptions of danger and risk at the border - and the implied roles of development organisations to combat these problems - provide a starting point for this paper. It has two main objectives: (1) to challenge state-based assumptions of contemporary border imaginaries in the sphere of cross-border development initiatives; and (2) to advance a multiperspectival approach to borders through the theoretical framework of 'place'. Although the concept of 'development' is contested by scholars concerned with power relations among developed and developing countries ${ }^{5}$ as well as the practical delivery of development projects. ${ }^{6}$ I choose to broadly think of it as describing processes of managed social, economic, and political change in a given society over time. The importance of such a wide conceptualisation for this paper is fourfold. First, it recognises how development is farreaching in terms of substantive issues. Second, by referring to 'managed' change, it introduces a dimension of intention, whether this comes at institutional, organisational, or individual levels. Third, it acknowledges that different kinds and sizes of actors (state, nonstate, corporate, individual) operating at different scales (local, national, regional, global) have potentially overlapping stakes in these intentional activities - and that these stakes can vary in a given time period. Fourth, it locates analysis from the perspective of societies in which development is occurring rather than assuming that change is imposed or passively 'received'.

While development is highly salient across Africa, it is especially important at borders, particularly where the networks of highways that carry large numbers of long-haul trucks cross the territorial boundaries of states. These networks are vital features because they facilitate commerce and migration: as can be seen on maps provided in official transport planning documents, they link major cities across the region. ${ }^{7}$ Multiple state and non-state actors - including local government authorities, international development agencies, nongovernmental organisations (NGOs), and charities that are subcontracted on projects - take a strong interest in these border locations. Their official aims revolve around preserving and growing economic capacity in these regions, as well as managing social change brought about by high levels of everyday internal and international migration.

For these reasons, I refer to development activities occurring at, across, or on the border using the hyphenated phrase 'inter-national development' to draw attention to my bordercentric perspective, in contrast to state-orientated and territorial assumptions that are subtly 
present in the phrase 'international development'. I am especially interested in highlighting how development as it occurs in the symbolic and physical 'margins' between states actually reveals a great deal about the contested nature of borders. ${ }^{8}$ Given this interest, this paper addresses the following questions: How do locally held border perceptions and practices on the part of development organisations contribute to the broader politics of cross-border development? What is the significance of these perceptions and practices for constructing Busia as a place of 'inter-national development'? Finally, to what extent does recasting borders in this way exemplify a multiperspectival approach?

Recent work on African cross-border development has usefully shown how perceptions of dangerousness in border regions are actually reconfiguring the roles of states and development organisations towards 'containment' activities rather than outright enforcement. ${ }^{9}$ Studies showing how security agencies at borders often benefit from 'illegal' smuggling or trade activities illustrate this point. ${ }^{10}$ Observing the range of (il)licit activities which occur in border regions, perceptions of danger and risk can arise among border residents through their very personal experiences, but are also located within wider geopolitical contexts which change over time. ${ }^{11}$ Linking to this literature, my broad argument is that theorising borders as 'places' - comprising geographic location, material forms, and subjectively-held perceptions, feelings, or practices ${ }^{12}$ - puts borders back at the centre of wider economic and social transformation rather than relegating them to the theoretical margins of social science. Local conceptions of 'the border' are not limited to conventional views of the visible state. They also reach across geographic scales to constitute and mediate varied perspectives on what it means to 'be at' a border.

The paper is structured in the following way. First, I review the main tenets and advantages of multiperspectival approaches to borders, paying particular attention to how this outlook is relevant to my conceptualisation of 'inter-national development' in Africa. Then, after outlining a theory of place as a way of operationalising this approach, I use a case study of cross-border development in East Africa to illustrate how organisations construct border activities as sources of danger in need of interventions. Next, the discussion section critically examines how these perceptions and practices surrounding local development efforts construct these border towns into 'places of development' that are implicated in multiple spatial scales. Finally, I conclude with reflections on how place theory makes a valuable contribution to broader themes in critical border studies.

\section{Methodology and Study Background}

To identify border perceptions and practices, as well as understand their significance for inter-national development, this study used a qualitative methodology inspired by previous critical border studies. ${ }^{13}$ Specifically, I focus on Busia, Uganda, and Busia, Kenya; these are two border towns along the Northern Corridor highway at the Kenya-Uganda boundary that are included in the ROADS II framework. ${ }^{14}$ Their examples provide valuable case studies for examining how the presence of a border figures in local development organisations' experiences in designing, delivering, and managing their projects. It is important to note that several groups in both towns called themselves 'development' organisations. These varied in terms of their administrative size, association with regional or international agencies, who they aimed to serve, and what kinds of projects they executed. Generally, however, they addressed issues of human welfare that have wider, societal consequences; these include accessing health services like HIV-AIDS testing and treatment, educating community members about available services, and facilitating some sort of support network for 
recipients. Their operations also tended to be framed around specific projects with the goal of measurable improvement over time. Finally, they often accumulated and deployed professional knowledge and expertise to formulate, execute, and evaluate projects.

Across the countries in which it operates, ROADS II is implemented using a 'cluster model' approach, whereby needs and resources specific to any given site are gathered around themes formulated by residents. ${ }^{15}$ Figure 1 , an illustration made into a poster, shows how the model is structured around themed clusters. Each cluster is 'anchored' by an implementing organisation that in turn reports to a regional branch of FHI. In Busia, Uganda there are seven clusters that link local groups with the aim of targeting different community members: LowIncome Women (LIW), Sauti Radio, People Living with HIV-AIDS (PLHA), Pharmacies, Youth, the Resource Centre (serving truckers via the Amalgamated Truckers and General Workers Union, or ATGWU), and Orphans and Vulnerable Children (OVC).

FIGURE 1 Poster depicting the ROADS II cluster model approach in Busia, Uganda.

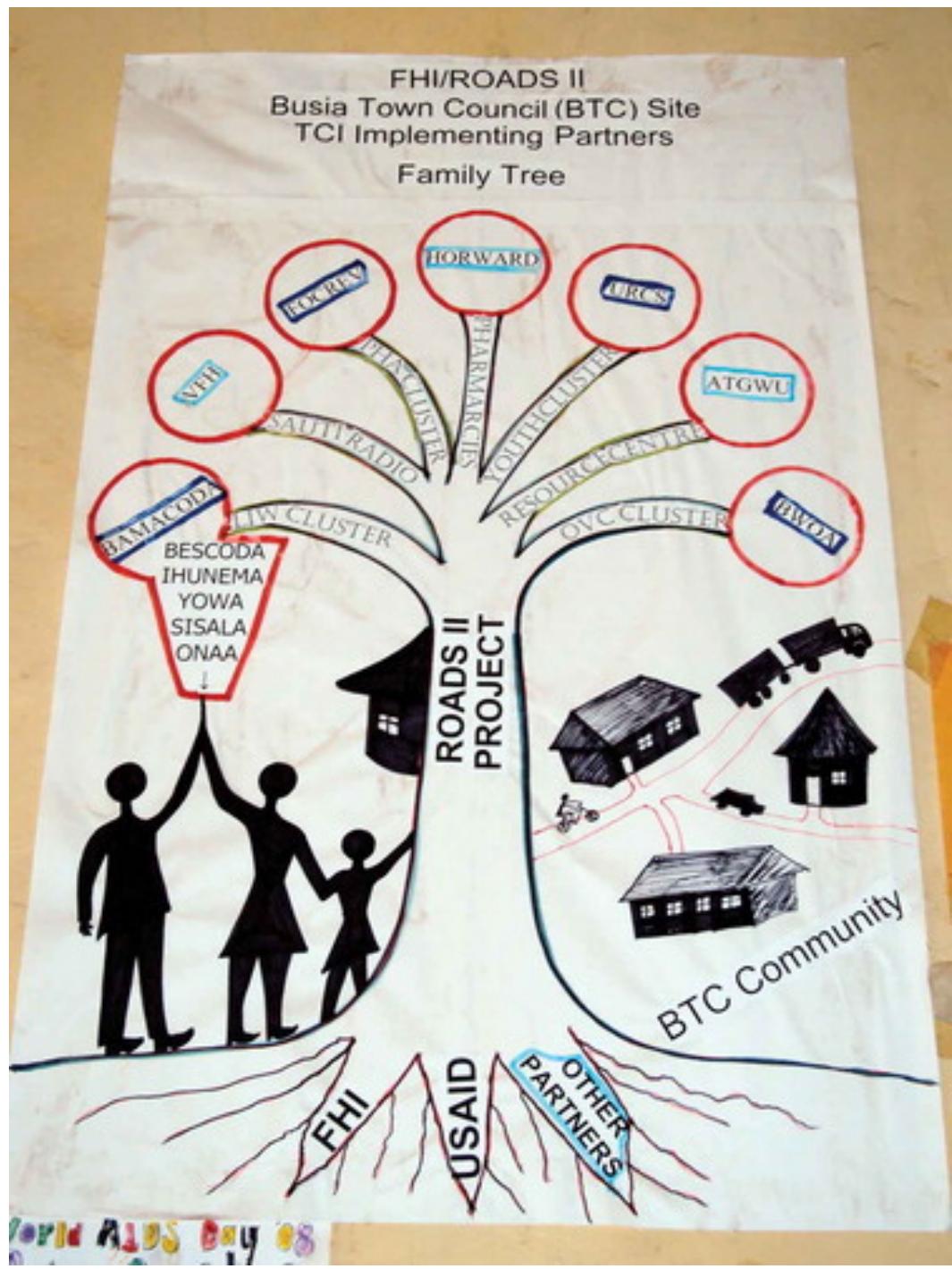

Initial interviews and participant observation revealed how three of these clusters - LowIncome Women, People Living with HIV/AIDS, and the Resource Centre - brought together development organisations and residents that were especially impacted by the presence of the border. The anchors of these clusters, Bajjabasaaga Marachi Community Development 
Association (BAMACODA), Friends of Christ Revival Ministries (FOC-REV), and the ATGWU respectively, were willing to participate in this study.

In addition to ROADS II, other organisations operating in both border towns also deal with similar issues of social development. Despite not being part of the official ROADS II structure, they also provide services aimed at improving the welfare of borderland residents and migrants travelling through Busia. Successful contact with four of the most established groups were made: Straight Talk, a Ugandan 'safe sex' media campaign aimed at school children; a Red Cross Heath Centre; Kenyan Survivors of Busia which provides peer counselling for women affected by HIV/AIDS; and the Busia branch of the Association of Disabled People of Kenya (ADPK) which supplies adaptive wheelchairs and rehabilitative care to people with mobility impairments. As reported in the empirical sections, these organisations also provided longer term insight into everyday life in Busia.

Fieldwork involved several methods which were iteratively deployed: (1) participant observation at and along the physical border as well as within the towns; (2) 28 semistructured ethnographic interviews with Kenyan and Ugandan border-crossers, residents, and development agencies; (3) four focus groups with people identified as key groups in the border region, including women engaged in commercial sex work, women affected by HIVAIDS either directly or indirectly, bicycle taxi drivers (called boda-boda men), and long-haul truckers; (4) a focus group held at the end of fieldwork with the participants which served as an important validity check as well as an opportunity to share initial findings and put the participants in contact with one another for future networking.

Since sensitive topics were discussed - particularly HIV-AIDS status, sexual practices, use of (il)legal substances, and access to available health services or treatment - two locally recruited assistants led the focus groups with translation available for the participants' preferred languages. All names and certain identifying details have been changed to protect participants' confidentiality.

\section{MULTIPERSPECTIVAL BORDER STUDIES AND 'SEEING LIKE A BORDER'}

In a recent special section of Geopolitics, Parker and Vaughan-Williams sought to formally restate the aims of critical border studies and engage with the heterogeneous concepts and methods associated with the field. ${ }^{16}$ They make two particularly insightful points. On the one hand, social and economic change has transformed how borders are practically perceived, felt, and undermined in specific situations. ${ }^{17}$ In many cases, these local observations exist alongside or outside of the purview of individual states. On the other hand, dominant approaches to borders and border practices remain closely tied - even defined in relation to conventional views of states. ${ }^{18}$ Borders are still "understood in simplest terms as the razoredge of the nation-state where mutually recognised sovereignties meet and yet do not overlap". ${ }^{19}$ Therefore, there is significant scope to break out of this "territorial trap" ${ }^{20}$ and return borders in their own right to the centre of broader social research.

In that special section, Chris Rumford argues for a 'multiperspectival approach' to border studies which advocates for, among several elements, the necessity of 'seeing like a border' as a possible way of overcoming the impasse between border theory and practice. ${ }^{21}$ As previous border scholars have explored in comparative fashion, ${ }^{22}$ the plurality of perspectives 
held at or on contemporary borders offer exciting and promising possibility for recasting borders' centrality to social, political, and economic life. ${ }^{23}$ Although Rumford's idea of 'seeing like borders' can be traced back to an earlier intervention on border thinking ${ }^{24}$ he has continued to develop this notion to highlight how "contemporary transformations cannot be properly understood from a single privileged vantage point and that events, processes, and actors can be interpreted differently from different perspectives" ${ }^{25}$ This involves "tak[ing] into account perspective from those at, on, or shaping the border, and this constituency is increasingly large and diverse". ${ }^{26}$

Specifically, this approach demands recognising three crucial characteristics of borders. First, they are deeply embedded in, and constitutive of broader social, political, and economic life rather than only markers of territory. Second, states do not always directly benefit from borders, but local border-crossers, migrants, and residents can tap into as well as transform notions of 'security' - and I would argue dangerousness - to benefit their own individual situations. Third, full analyses of borders or bordering activities must not be exclusively concerned with the 'marginal', but instead should capture how people actively engage in entrepreneurial practices: as Rumford asks, "Why remain passive in the face of other peoples' borders when you can obtain advantage by becoming a proactive borderer"? ${ }^{27}$ Extending Balibar's breakthroughs in border studies ${ }^{28}$ - specifically, those that revealed the relational nature of borders' meanings for diverse groups and individuals, as well as the fact that contemporary borders often do not correspond to conventional 'ends of territory' Rumford argues that a truly multiperspectival approach takes as its departure "the fact that some borders remain invisible, not usually to those on the outside but those living within, and that some borders exist for some people and not others". ${ }^{29}$ Indeed, as Balibar observes, "Territorial notions of 'interior' and 'exterior' are no longer completely separable, not even in a legal manner". ${ }^{30}$ Therefore, capturing these significances requires more than merely examining a given border from 'both sides' - from 'outside' a border, wherever that may actually be located.

Elements of this multiperspectival outlook are present in African border scholarship. ${ }^{31}$ Research emerging from such diverse fields as anthropology, sociology, history, geography, area studies, and migration studies has revealed how the material and imagined fixity of territory breaks down in the face of locally held perceptions about borders, ${ }^{32}$ dynamic differentials in economic advantage, ${ }^{33}$ weakened or non-existent state presence and institutions, ${ }^{34}$ and resistance by border-crossers themselves. ${ }^{35}$ Indeed, when compared to interior or capital cities, the presence of a border enables and disables different sets of economic and social practices in African border towns. ${ }^{36}$

There are some valuable examples of cross-border development as it exists in European policy and institutional contexts, ${ }^{37}$ as well as how they contrast with North American experiences. ${ }^{38}$ Perkmann and Sum observe how the concept of 'cross-border regions' as a formal policy instrument opens the possibility of examining how nation-states actively deploy sub-regional strategies for economic gain. ${ }^{39}$ However, there is a gap in empirical research which actively engages with border-crossers' or residents' own perspectives to demonstrate the significance of borders' impact on cross-border development projects as they are actually experienced at the local level. A recent exception comes from Gualda, Fragoso, and Lucio-Villegas, who examined community development efforts at the Spain-Portugal border. ${ }^{40}$ Using a macro-meso-micro level analytical framework that integrated regional, cross-border, and local community members' perspectives, they suggest that informal 
networks may be more significant for influencing development outcomes than formal institutions at the level of the nation-state.

Therefore, given the potential richness of a multiperspectival approach, there is significant scope for it to be theoretically or empirically operationalised. Parker and Vaughn-Williams observe the pressing need to "develop tools for identifying and interrogating what and where borders are and how they function in different settings, with what consequences, and for whose benefit". ${ }^{41}$ Previous authors have offered varied and multi-layered possibilities that span temporal and geographic scales: 'scapes' that are constructed by historical, linguistic, and political contexts ${ }^{42}$; 'Borderscapes' that are full of competing meanings which contest states' borders ${ }^{43}$; or 'spaces of flows' that coordinate and organise social practices across geographic distances regardless of state boundaries. ${ }^{44}$ These conceptualisations draw critical attention towards the increasingly diffuse ways that social, economic, and political activities spatially manifest themselves in cross-border contexts. ${ }^{45}$

However, while these concepts have rightfully pointed out the changing dynamics and characteristics of borders, they still risk tacitly framing analyses of borders from a statecentric view. Rather than seeing from borders, they risk only seeing borders from the outside as interstitial zones, sites of difference, or objects dependent on prior assumptions of states' ability to govern, securitise, or extract benefit from the 'lines in the sand' that mark their territory. What are needed are tools that can "plac[e] borders more centrally in relation to research on social and political transformations in the contemporary world and trea[t] the border as an object of study in its own right rather than subsumed to national sovereignty or state security ... freeing the border from an intrinsic relation to the nation-state". ${ }^{46}$ In the following section, I make the case for one such conceptual tool - well-established in human geography - and its usefulness as a multiperspectival approach to borders: place.

\section{PLACE AND 'BEING AT A BORDER'}

The discussion above reveals that taking an explicitly multiperspectival approach to borders requires capturing several dimensions. First, borders exist and reach across multiple scales other than the state. ${ }^{47}$ Second, they exert multifaceted influence upon - as well as are influenced by - border-crossers on their own terms, sometimes generating new connectivities as well as divisions. ${ }^{48}$ Third, these influences are dynamic: they do not remain constant, but have historical as well as potential characteristics. In short, full analysis of borders' significance must be non-essentialised, contingent, and sensitive to their interconnected links to other locations. ${ }^{49} \mathrm{I}$ argue that a theoretical framework of 'place' both encapsulates these dimensions and demonstrates their significance.

Theories of place are rooted in human geography, although they have been usefully applied in other social scientific and humanistic disciplines. ${ }^{50}$ Fundamentally, they examine the interaction of three elements: spatial or physical location; objects, materials, or built forms; and intangible practices or perceptions. ${ }^{51}$ These elements, although remaining distinct from each other, form a framework that gives greater meaning to a location that transcends spatial orientation. ${ }^{52}$ As the materiality of border locations changes, or the practices and perceptions among border residents or crossers change, the 'place' called 'the border' is transformed: "places are never complete, finished or bounded but are always becoming - in process". ${ }^{53}$ Cresswell's statement echoes Parker and Vaughan-Williams' own observation used in the 
Introduction: places, of which borders are one example, are always in a state of 'becoming' because the mix of people, things, and feelings that constitute them are also changing.

This dynamic theorisation of 'place' moves a multiperspectival approach into the realm of empirical analysis. Analyses using place theory actively seek out multiple viewpoints that emerge from careful observation of perceptions, practices, and materiality occurring at borders - as well as among people who interact with borders in all manner of ways that are not necessarily pre-determined by the states that 'govern' a given border. ${ }^{54}$ Furthermore, places are not monolithic entities for all people: rather, they are given particular meanings through individual and collective experiences. ${ }^{55}$ In this way, place theory makes a valuable contribution to critical border studies by putting the physicalities and experiences of 'being at a border' - in all their diversity and sometimes contradictory natures - back at the centre of theory development. ${ }^{56}$ Throughout the remaining paper, I will use this theory to make the case for seeing development 'like a border' - or, put in other words, to see borders as 'places of inter-national development'.

\section{SEEING FROM BUSIA: PERCEPTIONS OF DEVELOPMENT AND BORDER PRACTICES}

In this section, I report on four salient and interconnected development issues raised by organisation staff and ordinary residents: (1) treatment and prevention of HIV/AIDS in the face of commercial sex work; (2) addressing alcohol and drug addiction to both raise the level of community participation in projects and reduce the prevalence of unprotected sexual activity; (3) the bias of the towns towards services like bars, guesthouses, and informal trade which amplifies these problems by limiting the availability of other industries; and (4) practical and logistical concerns amplified by the border which impact organisations' abilities to address development issues. This is not to suggest that these issues are specific to Busia. For instance, HIV/AIDS and substance abuse are certainly present in other locations, and may in fact affect a greater number of people in absolute terms. However, as I go on to argue, viewing these development issues from an explicitly border-centric perspective reveals how everyday perceptions and practices are more significant than the sum of their parts might initially suggest.

\section{Commercial Sex Work and HIV/AIDS in the Border Towns}

Previous studies have shown how patterns of migration, as well as HIV-AIDS prevalence, tend to accompany highway trucking routes in Kenya and Uganda - particularly at the Busia border crossing points. ${ }^{57}$ In fact, many of the women in the study said they had moved to Busia from other districts in Uganda and Kenya because they had heard of opportunities for employment in bars and truck stops. A representative of FHI, the main partner of USAID in implementing the ROADS II project, explained,

We know that where trucks park, there is a haven for commercial sex workers. It's very common in Busia: you'll get a group of women coming from as far as Rwanda. They are coming following the trucks. Once there is anything that holds these trucks for more than two days here, you get an influx of people..$^{58}$

However, truckers are not the only people accessing sex workers; traders and farmers who deliver goods to the local markets also spend several days in Busia on each trip. Clearing 
agents, as they wait for shipments of agricultural products, similarly 'hang around' the towns. Furthermore, security officers and boda-boda drivers are involved in the business both as brokers and clients.

Amir, whose work with Straight Talk puts him in direct contact with all of the secondary schools in Busia District, explained that unprotected sex commanded higher prices than protected sex: "truckers pay 5,000 USh [Ugandan shillings] with a condom, but 50,000 USh without. If you have a child-headed household, of course they will take the 50,000 USh option to pay rent, buy food. They [truckers] have a lot of money". "Women involved in commercial sex complained "most of our clients do not use condoms or pay less if they do, yet we need the money". ${ }^{60}$ These observations illustrate one function of this border: as a temporary holding location where truckers and businessmen are prone to wait due to clearing procedures or inspection delays. Such a characteristic, most of the organisations conclude, is one of the largest reasons why Busia District experiences higher prevalence rates and contributes to Busia as a particular kind of place.

\section{Addiction to Alcohol and Other Drugs}

Development organisations also cited addiction as a problem that complicated efforts to intervene in 'unsafe' practices as well as promote healthier behaviour more generally. Unsurprisingly, given the quantity of bars and availability of alcohol, the district features high rates of addiction. However, it was common knowledge that residents also used significant quantities of other drugs - many of which were not produced locally but were carried back and forth via truckers, traders, and students from the interior. Gideon, a Ugandan staff member for BAMACODA, described an inhalant derived from paint:

There is this kind of inhalant that is for paint. A solvent. They sniff it, you know, to get intoxicated. There is a small girl who sometimes comes and lies around the front office. She looks like a zombie because of that thinner. That is another kind of stuff people are abusing here in Busia. You just see an adult wiping his nose with a handkerchief all the time [demonstrates]. You think he's sneezing, but he's sniffing the stuff. ${ }^{61}$

Another practice involved siphoning off fuel from idling trucks and using it as a kind of inhalant; several times whilst crossing, I observed boda-boda drivers crouching by their bicycles doing exactly this. Furthermore, Ugandan teachers admitted that they knew about students bringing in drugs from Kenya and using them on the premises: "They [Ugandan students] cross over and buy sachets of drugs. Then they hide them, and sniff it [demonstrates] and they get very drunk". ${ }^{62} 62$. Interview with Benjamin, 21 July 2010.View all notes

The draw of multiple bars present in the region is amplified by differentials in implementing district policy towards the consumption of alcohol:

Alcoholism influences people's sexual behaviour. It is a big problem. We have laws against alcoholism, drinking hours, which here are not practiced. In Kenya it is very strict. You are not allowed to be out drinking between 8:00 AM and 5:00 PM. So what the Kenyans do is they cross over into Uganda to booze, and they walk back. So they spend the whole day in bars here and of course all those activities are prime for disease. ${ }^{63}$ 
Kenyan employees of the ADPK also observed the degree to which this movement occurred as well as its impacts on the community:

David: Sometimes the Kenyans, they drink on the other side, and then they come back and are drunk in Kenya. They take the alcohol in Uganda and sleep in Kenya.

Researcher: They drink in Uganda and their home is in Kenya?

David: Yes. These ones [people making alcohol in Kenya], they become so commercial!

Researcher: Is it [the alcohol] as tasty?

David: No! So people would rather get the real thing from the other side.

We also find the problem of alcohol, more so because of the [border] interaction. The Kenyan side controls the use of alcohol. ... When there are Kenyans here, they go over to Uganda because it is controlled here. They take [drink] a lot. It affects the families. ${ }^{64}$

Gideon from BAMACODA put it more bluntly: "Come 5:00 PM, all roads lead to Uganda!" ${ }^{65}$ In the eyes of residents associated with development, addiction and substance abuse are linked to, and facilitated by, the presence of the border. This has ramifications for sexual behaviour accompanying the service-sector employment already present in the towns, further constructing Busia as a place that needs certain kinds of interventions.

\section{Economic Bias Towards Services in the Town Councils}

Accompanying truckers and traders are a range of people who provide food, drink, entertainment, and rest. Moses, the Ugandan staff member with FOC-REV, observed that "there are so many guest houses, we have so many banks, we have so many hotels - and all those service providers are dependent on the border being active. What makes all services active is the border". ${ }^{66}$ Peter from FHI echoed this sentiment, saying that "you also see this is a hub for produce buying and selling. You meet businessmen coming from as far as Nairobi. ... So that means there is disposable income, opportunities for people to get money, and ways to easily spend it". ${ }^{67}$ There are also many restaurants and informal stalls that sell cooked meals to traders while on the job. Meanwhile, children often assist in the maintenance and operation of these stalls lining the main streets.

It is clearly apparent that the incomes of ordinary people engaged in service provision are particularly sensitive to changes that impact the scale and frequency of border crossers who demand their services. Ugandan planning officials expressed concerns about the temporary and volatile nature of service-oriented businesses because their quality and monetary value were uncertain. Furthermore, they linked high levels of poverty in the district to a lack of investment in manufacturing. ${ }^{68}$ Over-reliance upon services for income in the town council is also problematic for development organisations: they perceive it as an enabler of unsafe sexual practices. Bashir, who worked with truckers visiting Busia's 'Safe-T-Stop', shared his view of the problem: 
Most of the indoor games, satellite television which provide different programmes like news, those things can be accessed in bars. And you find that at the end of the day, somebody engages in an activity he would not have actually wanted. You may go for news, but you would be forced to buy a bottle of beer in order to access the news. ${ }^{69}$

Amir, addressing the situation of young people in the town who choose to work in these informal service sector jobs rather than attend school, asserted that the lack of alternative choices also contributed to the town's problems:

There is no place for kids. The largest problem is idleness. I dream of a resource centre. You know, I'm very much into acting and drama; I did it in secondary school, some school plays. But if I wanted to practise my acting, where would I go? If I were a musician, where would I go? There is no place! ${ }^{70}$

Although the truckers' union seeks to interrupt these chains of activity emanating from the presence of truckers in the border region by providing alternative locations for them, it and other social development organisations serving residents and mobile people in the region recognise that the largely one-dimensional economic profile of the towns may limit future improvement. The frustrations expressed by border residents as well as development organisations also indicate how perceptions about Busia are linked to other scales and places through comparison of amenities that are lacking.

\section{Practical and Logistical Concerns for Development Organisations}

In additional to identifying pressing needs in the border towns, development organisations also expressed perceptions about how the border both facilitated as well as complicated their project-based efforts. These perceptions provided valuable insight into the nature of the border itself. On the one hand, there are important opportunities available to development organisations operating in the border region. For instance, given that actors on both sides of the border operate in a similar, project-based fashion with nearly identical goals, collaboration and sharing of expertise among these leaders is more likely. The scope for collaboration is amplified by the fact that recipients of these services cross back and forth themselves. Furthermore, as land trade flows increase, the fact that more people move towards the town council for employment, even if dominated by further gains in the service sector, opens the door for further investment in infrastructure as people demand more amenities.

On the other hand, development organisations identified significant challenges to their operations in the border region. First, how can a service be delivered to people who are highly mobile, when effective prevention and awareness campaigns require concerned efforts and investment of time to change behaviours?

We're continually getting new people to and from. People come from as far as Mombasa, from Nairobi. This border road, the great North Road, is full of truck. When it comes to passengers and truckers, they normally have a rest. In Busia. One night, they go; one night, they come. So you find you are not giving information to - you are not empowering people - who are living in the same place over time. ${ }^{71}$ 
Medical staff at the Red Cross Health Centre echoed this problem in the formulation of treatment plans. Muhamed, a Ugandan nurse who had been working at the Health Centre for several years, explained how ensuring that longer term regimens were actually completed was difficult when patients might be in Busia for only a short while:

In my own experience, [a trucker] started feeling unwell. He came from Kisumu [in Kenya] and he has arrived in Busia. He comes to me, but the next day the boss is saying 'go to Kampala, or Rwanda, in two days'. And his medication is for five days! And the guy cannot just stay around for five days - he has to move. So the challenge is noncompliance with the medication. It is very rare for people to comply. ... Or, someone is here doing business, tomorrow he has shifted to another unknown destination. Either the business here has collapsed or there is another opportunity somewhere. You can't follow it up. ${ }^{72}$

Also, not only can it be difficult to locate women engaged in commercial or transactional sex and convince them to be trained as a peer counsellor, but also there remains the possibility that they will move to follow trucking patterns: as some women expressed in the focus groups, "One of the problems is that after training peer educators, you find few are active or even around anymore". 73

Second, how can development organisations better coordinate their work among frequently targeted groups like truckers? Concerns about unnecessary duplication of projects, as well as inefficient use of limited time and monetary resources, impinge on trust among local residents and the organisations themselves. Viewing the significant needs present in the border region, as well as the financial attention given by USAID, it is no surprise that many actors deliberately target Busia for their activities. Bashir, the Safe-T-Stop staff member, expressed frustration at what he saw as the uncoordinated, overlapping efforts in the town council:

It is important to coordinate with other key partners. A lot of money is pumped, but we don't know where it goes! We have so many key players, but we don't know who they are. Yet, we are all working with the same mobile populations, like truckers. ${ }^{74}$

Community members' prior interactions with larger, multinational development organisations also complicated local efforts to build and maintain trust over time:

There are other programmes which are giving out money to the same community; it's like there is duplication of services. Yes. If we are saying we are behaviour changing, and we are targeting women who are in the sex industry, then another organisation comes along with the same. So it gives us hardship because it makes us talk a lot to explain. At the end of the day, not all will agree with us. They [community members] will say 'you guys, we don't trust you. You have been given money to give us, and yet you don't. So why are the others giving to us? ${ }^{75}$

Although these problems of programme coordination, presentation, and delivery are not unique to organisations operating at the border, they do highlight ways by which the border and its associated inhabitants make a real impact in development enterprises. These kinds of 
issues, perhaps more than others previously raised, especially illustrate how border towns are sites of 'inter-national' development.

\section{INTER-NATIONAL DEVELOPMENT AT BORDERS: A MULTIPERSPECTIVAL APPROACH}

At the outset, I put forward three main questions: (1) How do locally held border perceptions and practices on the part of development organisations contribute to the broader politics of cross-border development? (2) What is the significance of these perceptions and practices for constructing borders as places of 'inter-national development'? (3) To what extent does recasting borders in this way exemplify a multiperspectival approach? The previous section illustrated how development in Busia - as a set of managed change aimed at reducing HIV/AIDS prevalence and substance abuse - is impacted by the presence of the border. By presenting opportunities for interaction and connection as well as challenges for programme coordination, the border complicates how development practice unfolds in Busia while simultaneously contributing to perceptions of danger and risk. However, I argue that framing development at borders in terms of dichotomies - opportunities and challenges, advantages and disadvantages, 'this' side and 'that' side - only captures part of the story of why borders are so significant in everyday life. To get at the broader picture, I argue that place theory synthesises crucial elements of location, material forms, and intangible perceptions or practices into a holistic analysis of what it means to be in and at a border.

\section{TABLE 1 Analysing Busia through the lens of place}

[about here]

\section{Busia as a Border Place}

Looking through this lens of place shows how Busia is deeply interconnected across micro-, meso-, and macro-level scales, enabling it to speak to border development elsewhere. As depicted in Table 1, my organisation of place includes these three levels of analysis which correspond to the framework of Gualda, Fragoso, and Lucio-Villegas. ${ }^{76}$ First, in terms of geographic location, these border towns are not just located at the physical conjoining of two states, which is where most conventional border analyses might start and end. Rather, they are prominent features on an extensive road network stretching across eastern and central Africa - a network which can be thought of as a borderland itself. ${ }^{77}$ At the micro level, the 'border' actually refers to a set of gates at the formal crossing between the two towns. Moving a few kilometres on either side of the towns reveals informal rut paths called panyos that traders and border-crossers use to expedite movement or circumvent official state policies on taxation. At both scales, attention from development organisations is acute and directed at Busia precisely because of its physical location.

Second, the specific mix of Busia's border materiality figures in its development needs and profile. Land crossings, particularly along vital road networks, often feature customs and security posts. Busia is no exception. Therefore, patterns of long-haul trucks play vital roles in shaping what kinds of services are available and desirable in the towns where they stop for inspection. Meanwhile, differentials in the availability, price, and quality of goods on either side of the physical border mean that there is a high volume of cross-border trade. Not all of this trade originates in the immediate borderland, however. Other centres of manufacturing 
and production, such as the port city of Mombasa in Kenya, the capital cities of Kampala and Nairobi, or the interior farmlands that generate agricultural goods for export - also contribute to Busia's economy.

Finally, everyday practices and perceptions surrounding development efforts in Busia are also key for understanding what it means 'to be at' a border. In this case, the most obvious kind of practice involves crossing the physical border. Whether referring to truckers moving with their cargoes, boda-boda drivers moving people and goods, students going to school, or residents going about their daily shopping and trading, the act of crossing back and forth carries a great deal of importance for everyday life in Busia. Widening the scope to include Busia's relationship to other cities along the highway network reveals that migratory practices - largely dictated by, but not exclusively defined in terms of long-haul trucking also contribute to the specific types of people attracted to the border for perceived economic opportunities. Yet, exclusively constructing Busia as a destination ignores the fact that many border-crossers view and use it as a stopover - one of many temporary holding points along a busy economic lifeline. Therefore, physical and temporal transience are important considerations in analysing Busia through the lens of place.

\section{Busia as an Example of 'Inter-national' Development}

How does this analysis relate to development practice occurring in the border towns? Throughout this paper, I have used the concept of 'inter-national' development to signal my border-centric analysis, locating it simultaneously between and beyond the purview of the Kenyan and Ugandan states. I argue that viewing the border as a "place of inter-national development' reveals how its unique mix of location, materiality, and intangible perceptions or practices creates a complex environment in which different versions of what it means to 'do' development are possible.

For example, one perspective on development as illustrated by staff members' own reflections could go as follows: high levels of trucking contribute to the service-oriented profile of the towns as well as increasing the likelihood of sexual behaviour labelled as 'risky'. In turn, this lively border economy both attracts and supports larger development projects as exemplified by the numerous clusters in ROADS II. Yet, this story is complicated by another, more critical perspective that observes how development practice in the border region is overcrowded and one-dimensional: development organisations themselves admitted that there were few opportunities for employment outside of local government: "If you aren't working for a volunteer organisation or the district [council], there is not much else". ${ }^{78}$ As projects proliferate and overlap in scope, staff must deal with the risk of becoming inefficient - not least of all because of the practical challenges of delivering project aims such as health treatment and awareness building in a place characterised by transient and unpredictable mobility.

\section{Generating Multiple Perspectives on the Border}

The question that remains is how to link a place-based analysis of inter-national development to Rumford's multiperspectival approach. Viewing Busia as a border place highlights how different individuals living in the towns - not all of whom work in formal development organisations under the ROADS II framework - express different development needs. Some of these needs are predicated on perceptions of dangerousness: practical delivery of HIV/AIDS screening and other health services to mobile populations, proliferation of 
addictive substances, the towns' bias towards temporary services rather than industries. They also implicate a range of causes for these issues, including the predominance of long-haul trucking, differences or outright gaps in policies, and delays in crossing the border proper.

What lies at the heart of this discussion are multifaceted perceptions about what the border does and represents for these individuals. It is at once a magnet for commerce, a loosely bounded container for traders and truckers who cross, a porous filter for small-scale drugs smuggling, a marker of policy difference, a zone of sexual activity, a hive of development organisations. It is a place of mixed-advantage, of waiting, of outcomes that are seen by some as uncertain, risky, and sometimes dangerous. By intentionally seeking and uncovering the range of intangible feelings, perceptions, and practices occurring at the border as well as other scales - while also recognising the realities of dissonance, contradiction, constructedness, and change at borders - place theory actualises a multiperspectival approach. It begins to liberate border scholars from the trap of territory through an appreciation of how locations like borders are filled with meaning, and then linked to other places that do not necessarily correspond to conventional states.

Place theory could be usefully applied to further study of inter-national development at borders in Africa. For example, comparative research at multiple border crossing sites would reveal whether and how the perceived 'threat' of long-haul trucking transfers to other communities which may have their own unique mix of available resources, locational advantages, and everyday border-crossing practices. Also, deeper discursive analysis of development organisations' own programme formulation, design, and implementation would show how certain stated values, perceptions, and feelings about 'the border' compare with staff members' opinions about what border communities actually 'need'. Appreciating multiple perspectives on border life opens avenues for empirically developing the richness presented by such 'sight from borders' through thoughtful engagement with processes of borders' continual becoming.

\section{ACKNOWLEDGEMENTS}

The author would like to thank Oliver Bakewell for his helpful and illuminating comments on an earlier version of this paper, as well as the three referees and editorial staff of Geopolitics for their insightful feedback.

\section{Notes}

1. Noel Parker, and Nick Vaughan-Williams, 'Critical Border Studies: Broadening and Deepening the 'Lines in the Sand' Agenda', Geopolitics 17/4 (2012) p. 728.

2. Family Health International, 'ROADS II Project Overview', available at $<$ http://www.fhi360.org/sites/default/files/media/documents/ROADS\%20II\%20Regional\%20 Brief.pdf $>$, accessed 3 Nov. 2013.

3. Family Health International, 'Roads I and II: Paving the Way for Healthier Communities', available <http://www.fhi360.org/sites/default/files/media/documents/ROADS_052013_web_nocrops .pdf>, accessed 3 Nov. 2013. 
4. Interview with Moses, 17 July 2010.

5. Arturo Escobar, Encountering Development: The Making and Unmaking of the Third World, Princeton Studies in Culture/Power/History (Princeton: Princeton University Press 1995).

6. Mark Hobart, An Anthropological Critique of Development: The Growth of Ignorance (London: Routledge 1993); Philip Quarles van Ufford, 'Knowledge and Ignorance in the Practices of Development Policy', in Mark Hobart (ed.), An Anthropological Critique of Development: The Growth of Ignorance (London: Routledge 1993).

7. East African Community Infrastructure, 'East African Community Road Network Project', available at $<$ http://www.eac.int/infrastructure/index.php?Itemid=129>, accessed $20 \mathrm{Feb}$. 2014.

8. Veena Das and Deborah Poole (eds.), Anthropology in the Margins of the State (Oxford: James Currey 2004).

9. Wolfgang Zeller, 'Danger and Opportunity in Katima Mulilo: A Namibian Border Boomtown at Transnational Crossroads**', Journal of Southern African Studies 35/1 (2009) pp. 133-154.

10. Kristof Titeca, 'The 'Masai' and Miraa: Public Authority, Vigilance and Criminality in a Ugandan Border Town', The Journal of Modern African Studies 47/2 (2009) pp. 291-317; Wolfgang Zeller, 'Neither Arbitrary nor Artificial: Chiefs and the Making of the NamibiaZambia Borderland', Journal of Borderlands Studies 25/2 (2010) pp. 6-21.

11. Martin Doevenspeck, 'Constructing the Border from Below: Narratives from the Congolese-Rwandan State Boundary', Political Geography 30/3 (2011) pp. 129-142; Kristof Titeca, and Tom De Herdt, 'Regulation, Cross-Border Trade and Practical Norms in West Nile, North-Western Uganda', Africa 80/4 (2010) pp. 573-594.

12. John Agnew, 'Representing Space: Space, Scale and Culture in Social Science', in James S. Duncan and David Ley (eds.), Place/Culture/Representation(London: Routledge 1993).

13. Nick Megoran, 'For Ethnography in Political Geography: Experiencing and ReImagining Ferghana Valley Boundary Closures', Political Geography 25/ (2006) pp. 622640; Sharon Pickering, and Leanne Weber, Borders, Mobility and Technologies of Control (The Netherlands: Springer 2006); Timothy Raeymaekers, 'The Silent Encroachment of the Frontier: A Politics of Transborder Trade in the Semliki Valley (Congo-Uganda)', Political Geography 28/ (2009) pp. 55-65.

14. Susan Whyte, and Herbert Muyinda, 'Wheels and New Legs: Mobilization in Uganda', in Benedicte Ingstade and Susan Reynolds Whyte (eds.), Disability in Local and Global Worlds (Berkeley: University of California Press 2007).

15. FHI (note 3).

16. Parker and Vaughan-Williams (note 1) pp. 727-733. 
17. David Spener and Kathleen A. Staudt, The US-Mexico Border: Transcending Divisions, Contesting Identities (Boulder: Lynne Rienner Publishers 1998).

18. Patricia Price, 'Inscribing the Border: Schizophrenia and the Aesthetics of Aztlan', Social \& Cultural Geography 1/1 (2000) pp. 101-116.

19. Parker and Vaughan-Williams (note 1).

20. John Agnew, 'The Territorial Trap: The Geographic Assumptions of International Relations Theory', Review of International Political Economy 1/1 (1994) pp. 53-80.

21. Chris Rumford, 'Towards a Multiperspectival Study of Borders', Geopolitics 17/4 (2012) pp. 887-902.

22. Victor Konrad and Heather N. Nicol, 'Border Culture, the Boundary between Canada and the United States of America, and the Advancement of Borderlands Theory', Geopolitics 16/1 (2011) pp. 70-90; Doris Wastl-Walter (ed.), The Ashgate Research Companion to Border Studies (Farnham, UK: Ashgate 2011).

23. Johan Schimanski and Stephen Wolfe, 'Cultural Production and Negotiation of Borders: Introduction to the Dossier', Journal of Borderlands Studies 25/1 (2010) pp. 38-49.

24. Corey Johnson, Reece Jones, Anssi Paasi, Louise Amoore, Alison Mountz, Mark Salter, and Chris Rumford, 'Interventions on Rethinking 'the Border' in Border Studies', Political Geography 30/2 (2011) pp. 61-69.

25. Rumford (note 21) p. 893.

26. Ibid.

27. Ibid.

28. Etienne Balibar, Politics and the Other Scene (London: Verso 2002); Etienne Balibar, 'Europe as Borderland', The Alexander von Humboldt Lecture in Human Geography (Nijmegen: University of Nijmegen 2004).

29. Rumford (note 21) p. 894.

30. Balibar, 'Europe as Borderland' (note 28) p. 23.

31. Veena Das and Deborah Poole (eds.), Anthropology in the Margins of the State (Oxford: James Currey 2004).

32. Donna K Flynn, "We Are the Border": Identity, Exchange, and the State Along the Bénin-Nigeria Border', American Ethnologist 24/2 (1997) pp. 311-330.

33. Dereje Feyissa and Markus Hoehne (eds.), Borders and Borderlands as Resources in the Horn of Africa (Oxford: James Currey 2010). 
34. Oliver Bakewell, 'The Meaning and Use of Identity Papers: Handheld and Heartfelt Nationality in the Borderlands of North-West Zambia', International Migration Institute Working Papers (2007).

35. Paul Nugent and Anthony I. Asiwaju (eds.), African Boundaries: Barriers, Conduits and Opportunities (London: Pinter 1996); David B. Coplan, 'Siamese Twin Towns and Unitary Concepts in Border Inequality', in Ulf Engel and Paul Nugent (eds.), Respacing Africa (Leiden, Netherlands: Koninklijke Brill NV 2010).

36. Pierre-Yves le Meur, 'State Making and the Politics of the Frontier in Central Benin', Development and Change 37/4 (2006) pp. 871-900.

37. Viktoriya Khasson, 'Cross-Border Cooperation over the Eastern EU Border: Between Assistance and Partnership under the European Neighbourhood and Partnership Instrument', East European Politics 29/3 (2013) pp. 328-343; James Wesley Scott and Ilkka Liikanen, 'Civil Society and the 'Neighbourhood': Europeanization through Cross-Border Cooperation?', European Integration 32/5 (2010) pp. 423-438.

38. Joachim Blatter and Norris Clement, 'Introduction to the Volume: Cross-Border Cooperation in Europe: Historical Development, Institutionalization, and Contrasts with North America', Journal of Borderlands Studies 15/1 (2000) pp. 14-53.

39. Markus Perkmann and Ngai-Ling Sum, Globalization, Regionalization, and CrossBorder Regions (New York: Palgrave Macmillan Basingstoke 2002).

40. Estrella Gualda, António Fragoso, and Emilio Lucio-Villegas, 'The Border, the People and the River: Development of the Cross-Border Area between Southern Spain and Portugal', Community Development Journal 48/1 (2013) pp. 23-39.

41. Parker and Vaughan-Williams (note 1) p. 729.

42. Arjun Appadurai, 'Disjuncture and Difference in the Global Cultural Economy', in M. Featherstone (ed.), Global Culture: Nationalism, Globalization and Modernity (London: Sage 1990).

43. Prem Kumar Rajaram and Carl Grundy-Warr (eds.), Borderscapes: Hidden Geographies and Politics at Territory's Edge (Minneapolis: University of Minnesota Press 2007).

44. Manuel Castells, The Rise of the Network Society (London: Wiley Blackwell 2000).

45. Gabriel Popescu, Bordering and Ordering the 21st Century: Understanding Borders (Lanham, MD: Rowman \& Littlefield Publishers 2012).

46. Rumford (note 21) pp. 809-810.

47. Sean L'Estrange and Liam O'Dowd, 'Structures and Narratives of Border Change: Perspectives from North America, Europe and the Middle East', Journal of Borderlands Studies 23/1 (2008) pp. 1-11. 
48. Huib Ernste, Henk Van Houtum, and Annelies Zoomers, 'Trans-World: Debating the Place and Borders of Places in the Age of Transnationalism', Tijdschrift voor economische en sociale geografie, 100/5 (2009) pp. 577-586.

49. Doreen Massey, 'The Possibilities of a Politics of Place Beyond Place? A Conversation with Doreen Massey’, Scottish Geographical Journal 125/3-4 (2009) pp. 401-420.

50. Yi-Fu Tuan, 'Language and the Making of Place: A Narrative-Descriptive Approach', Annals of the Association of American Geographers 81/4 (1991) pp. 684-696; Trevor Barnes, “"This Is Like Deja Vu All over Again”“, The Professional Geographer 63/3 (2011) pp. 332-336.

51. Tim Cresswell, Place: A Short Introduction (Oxford: Blackwell 2004); Linda McDowell, Gender, Identity and Place (Minneapolis: University of Minnesota Press 1999).

52. Thomas F. Gieryn, 'A Space for Place in Sociology', Annual Review of Sociology 26 (2000) pp. 463-496.

53. Cresswell (note 51) p. 37.

54. Arturo Escobar, 'Culture Sits in Places: Reflections on Globalism and Subaltern Strategies of Localization’, Political Geography 20 (2001) pp. 139-174.

55. Edward S. Casey, 'Border Versus Boundary at La Frontera', Environment and Planning D: Society and Space 29/3 (2011) pp. 384-398.

56. Ruben Gielis, 'A Global Sense of Migrant Places: Towards a Place Perspective in the Study of Migrant Transnationalism', Global Networks 9/2 (2009) pp. 271-287.

57. Alan G. Ferguson, and Chester N. Morris, 'Mapping Transactional Sex on the Northern Corridor Highway in Kenya', Health \& Place 13/2 (2007) pp. 504-519.

58. Interview with Peter, 16 Aug. 2010.

59. At the time of fieldwork, 5,000 Ugandan shillings were worth about GBP $£ 1.50$, or USD \$2. Meanwhile, 50,000 Ugandan shillings were worth about GBP $£ 15$, or USD \$20. However, given the illustrative nature of Amir's comments at this time in the interview, these figures should not be interpreted as specific figures, but rather as evidence of practices and understandings surrounding commercial sex work and condom usage. Interview with Amir, 9 Aug. 2010.

60. Anette, focus group, 20 July 2010.

61. Interview with Gideon, 30 July 2010.

62. Interview with Benjamin, 21 July 2010.

63. Peter (note 58).

64. Interview with David, 4 Aug. 2010. 
65. Gideon (note 61).

66. Moses (note 4).

67. Peter (note 58).

68. Interview with District Official \#2, 15 Aug. 2010.

69. Interview with Bashir, 29 July 2010.

70. Amir (note 59).

71. Moses (note 4).

72. Interview with Muhamed, 12 Aug. 2010.

73. Asha, focus group, 23 July 2010.

74. Bashir (note 69).

75. Gideon (note 61).

76. Gualda, Fragoso, and Lucio-Villegas (note 40).

77. Zeller, 'Danger and Opportunity' (note 9).

78. Peter (note 58). 